\title{
Planococcus halophilus sp.nov., a Facultatively Halophilic Coccus
}

\author{
T. J. NOVITSKY ${ }^{1}$ AND D. J. KUSHNER \\ Department of Biology, University of Ottawa, Ottawa, Ontario K1N 6N5, Canada
}

\begin{abstract}
National Research Council of Canada (NRCC) strain 14033 is a gram-variable, motile, yellow-pigmented, strictly aerobic, facultatively halophilic coccus. The guanine plus cytosine content of the deoxyribonucleic acid of this strain is $50.4 \pm$ $0.7 \mathrm{~mol} \%$. This strain belongs to the genus Planococcus but differs from the neotype strain (CCM 316) of the type species, Planococcus citreus, in cell wall composition and $\mathrm{NaCl}$ requirement; unlike strain CCM 316, strain NRCC 14033 possesses meso-diaminopimelic acid in its cell wall peptidoglycan, and it cannot grow on nutrient medium at $30 \mathrm{C}$ without added $\mathrm{NaCl}$. We regard this strain as belonging to a new species, for which we propose the name Planococcus halophilus. Since the original description is based on a single strain, this strain is the type strain by monotypy. It has been deposited in the American Type Culture Collection under the number 27964.
\end{abstract}

A motile, facultatively halophilic coccus, obtained from the culture collection of the $\mathrm{Na}$ tional Research Council of Canada (NRCC) and designated NRCC 14033, is of special interest due to its ability to grow over a wide range of $\mathrm{NaCl}$ concentrations (16).

Although the NRCC culture collection previously listed NRCC 14033 as the obligate halophile "Micrococcus $\mathrm{H}_{5}$," originally isolated from salted mackerel by Venkataraman and Sreenivasan (28), our initial study indicated that the present NRCC 14033 is a facultative halophile and therefore is probably not "Micrococcus $\mathrm{H}_{5}$ " (16).

The work reported here was undertaken to determine the taxonomic niche of this strain.

\section{MATERIALS AND METHODS}

Stock cultures were maintained at $4 \mathrm{C}$ on the salt agar medium of Gibbons (6), which had the following composition (grams per liter): tryptone, 5.0; proteose-peptone, 5.0; NaCl, 58.4; agar, 20.0.

For morphological, cultural, and physiological studies, 24-h-old cultures were used. All test media, except blood agar plates, were modified to contain 1 $\mathrm{M} \mathrm{NaCl}$. Incubation was at $30 \mathrm{C}$ unless otherwise noted.

Hucker's modification of the Gram staining procedure was followed (8). Flagella were stained by the method of Leifson (12). Counterstaining was omitted for photomicrography. Photomicrographs were taken with a Zeiss planochromat microscope equipped with Nomarski optics.

Motility, heat resistance, and spore formation were studied as recommended by Kocur et al. (11).

Utilization of carbohydrates was determined using marine oxidation/fermentation (MOF) medium (13). Production of hydrogen sulfide and phenylala-

\footnotetext{
1 Present address: Woods Hole Oceanographic Institution, Woods Hole, Mass. 02543.
}

nine deaminase and the ability to grow on Simmons citrate agar were determined by the methods described by Ewing (3). The benzidine test was used to detect porphyrin-containing enzyme systems (2). Esculin hydrolysis and nitrite reduction were determined using the methods described by Sneath (25). Smith tube cultures containing $0.2 \% \mathrm{KNO}_{3}$ were checked for nitrate reduction with sulfanilic acid (17). Cultures for nitrite and nitrate reduction were checked daily for a period of 2 weeks. Catalase was detected by adding $3 \% \mathrm{H}_{2} \mathrm{O}_{2}$ directly to growth on plates. Oxidase was tested for with filter paper strips saturated with a $1 \%$ aqueous solution of tetramethyl- $p$-phenylenediamine and by the method of Gaby and Hadley (4). Growth on nutrient agargelatin plates was checked for gelatinase activity by flooding the plates with $\mathrm{HgCl}_{2}$ solution (10). Indole production was tested for by the cotton-wool method (7) using cultures grown on the medium recommended by Gibbons (5). Acetylmethyl-carbinol production was assayed with Burritt reagent (17) using cultures grown on MR-VP test medium (Difco) and by the method of Smith et al. (24). Ammonia production was checked with Nessler reagent using cultures grown on $4 \%$ peptone broth (17). The ability to hydrolyze starch was determined by adding Lugol iodine to growth on plates of the following composition (g/liter): tryptone, 10.0; yeast extract, 10.0; soluble starch, 20.0; $\mathrm{K}_{2} \mathrm{HPO}_{4}, 5.0 ; \mathrm{NaCl}$, 58.4; agar, 15.0. Casein hydrolysis was tested for using nutrient agar plates containing $2 \%$ skim milk. Urease was tested on Christensen medium (29). Lipase activity was determined using spirit blue agar (Difco) containing lipase reagent (Difco). Tween 80 hydrolysis was tested for by the method of Kocur and Hodgkiss (10). Hemolytic at ility was checked on blood agar plates (Qualicum Hospital and Lab Supply, Ltd., Ottawa). Incubation of blood plates was at $20 \mathrm{C}$ for 2 weeks. The $\mathrm{NaCl}$ content of the blood agar plates was $0.85 \%$. Coagulase production was checked with both rabbit and human sera (17). A coagulase-positive strain of Staphylococcus aureus was used as a control. 
Sensitivity to antibiotics was tested using Dispens-o-discs (Difco).

Deoxyribonucleic acid (DNA) was extracted by the method of Marmur (14). The guanine plus cytosine $(\mathrm{G}+\mathrm{C})$ content of the extracted DNA was determined using both the absorbance ratio method of Ulitzer (27) and the melting temperature $\left(T_{m}\right)$ method of Marmur and Doty (15). Escherichia coli B DNA (type VIII, Sigma Chemical Co.) was used as a standard.

Amino acid and amino sugar analyses were carried out with an amino acid analyzer on hydrolysates of peptidoglycan obtained by the method of Schleifer and Kandler (22). Conditions for hydrolysis were $6 \mathrm{~N} \mathrm{HCl}$ for $18 \mathrm{~h}$ at $100 \mathrm{C}$. Samples were contained in sealed evacuated hydrolysis tubes. The configuration of diaminopimelic acid (DAP) was determined chromatographically (19).

Specimens for thin-section observation were fixed by the method described by Ryter et al. (20), dehydrated in a graded acetone series, and embedded by the method of Spurr (26). Sections on copper grids were doubly stained with uranyl acetate and Reynolds lead citrate (18). Specimens for flagella measurement (shadow-cast) were prepared by the method described by Kocur et al. (11). Electron microscopy was performed with an Applied Electronics Industries EM6B electron microscope operating at a voltage of $60 \mathrm{kV}$.

\section{RESULTS}

Morphology. The cells of NRCC 14033 were gram-variable cocci, 0.5 to $0.8 \mu \mathrm{m}$ in diameter, occurring singly, in pairs, and ocassionally in groups of three and in tetrads. Spores were not detected. Motile cells were found in young cultures from both solid and liquid media. Paired cells were the predominant motile arrangement (Fig. 1). Motility was observed as a tumbling motion. Cells usually possessed one or two flagella. The flagella showed a regular sine curvature with a wavelength of $4.0 \mu \mathrm{m}$ and an amplitude of $0.6 \mu \mathrm{m}$ (Fig. 1). The flagellar diameter was approximately $40 \mathrm{~nm}$ (measured from electron micrographs of shadowed specimens, data not shown). Flagella up to $20 \mu \mathrm{m}$ long were found. Thin sections revealed a morphology typical of gram-positive bacteria (Fig. 2). Cells possessed a thick $(50 \mathrm{~nm})$, uniformly staining cell wall. Mesosomes were present. In some cells, cytoplasmic inclusions were observed (Fig. 3).

Cultural characteristics. Colonies on salt agar or nutrient agar containing $\mathrm{NaCl}$ were smooth, circular, entire, glistening, slightly convex, and produced a yellow-orange, waterinsoluble pigment. Growth on salt agar slants was filiform, mucoid, and pale yellow to yelloworange in color. In salt broth or nutrient broth containing $\mathrm{NaCl}$, slight turbidity with sediment was formed. The organism is strictly aero- bic. Growth was observed in the ranges 10 to 37 $\mathrm{C}$ and approximately 0 to $5.5 \mathrm{M} \mathrm{NaCl}$ (16). The bacterium grew well in seawater medium but poorly, and then only at temperatures lower than $30 \mathrm{C}$, on media without added salt. Optimum $\mathrm{NaCl}$ concentration for growth was between 1 and $2 \mathrm{M}$. If a cell suspension of optical density 1.0 (measured at $660 \mathrm{~nm}$ in an 18-mm cuvette) was heated at $50 \mathrm{C}$ for $15 \mathrm{~min}$, some cells survived, but all were killed after $15 \mathrm{~min}$ at $60 \mathrm{C}$.

Susceptibility to the following antibiotics was observed: lysozyme; penicillin, 5 IU; tetracycline, $5 \mu \mathrm{g}$; erythromycin, $5 \mu \mathrm{g}$; chloramphenicol, $10 \mu \mathrm{g}$; and novobiocin, $5 \mu \mathrm{g}$. The organism was resistant to streptomycin $(5 \mu \mathrm{g})$ and sulfisoxazole $(150 \mu \mathrm{g})$.

Biochemical characteristics. The organisms showed positive catalase and benzidine tests. Gelatin was hydrolyzed. Slight acid was produced from glucose aerobically in MOF medium after 10 days. Lipolysis was observed with lipase reagent (Difco) but Tween 80 was not hydrolyzed. The organism was negative with regard to the following: coagulase production; acid production from mannitol, lactose, maltose, arabinose, galactose, sucrose, and fructose; reduction of nitrate and nitrite; production of indole, acetylmethylcarbinol, phosphatase, hydrogen sulfide, ammonia, phenylalanine deaminase, and urease. The bacterium grew as small white colonies on blood agar, but no hemolysis was observed. No growth occurred on Simmons citrate agar. Starch and casein were not hydrolyzed.

The DNA of this organism contained $50.4 \pm$ $0.7 \mathrm{~mol} \% \mathrm{G}+\mathrm{C}$ as determined spectrophotometrically. The mol\% $\mathrm{G}+\mathrm{C}$ was also determined on the same sample from temperaturemelting data as a check on the photometric method. A value of 50 to $51 \mathrm{~mol} \%$ was obtained from the $T_{m}$.

The amino acid and amino sugar composition of the peptidoglycan cell wall component is shown in Table 1.

\section{DISCUSSION}

Although NRCC 14033 was formerly listed by the NRCC culture collection as "Micrococcus $\mathrm{H}_{5}$," our previous study of its growth characteristics (16) and our present results support the conclusion that NRCC 14033 is not the "Micrococcus $\mathrm{H}_{5}$ " originally reported by Venkataraman and Sreenivasan (28). To verify this, another culture listed as "Micrococcus $\mathrm{H}_{5}$ " was obtained from the National Collection of Marine Bacteria (NCMB), Torry Research Station, Aberdeen, Scotland. This organism, NCMB 725 , was identical to Venkataraman and Sreenivasan's original description (T. J. Novitsky and 

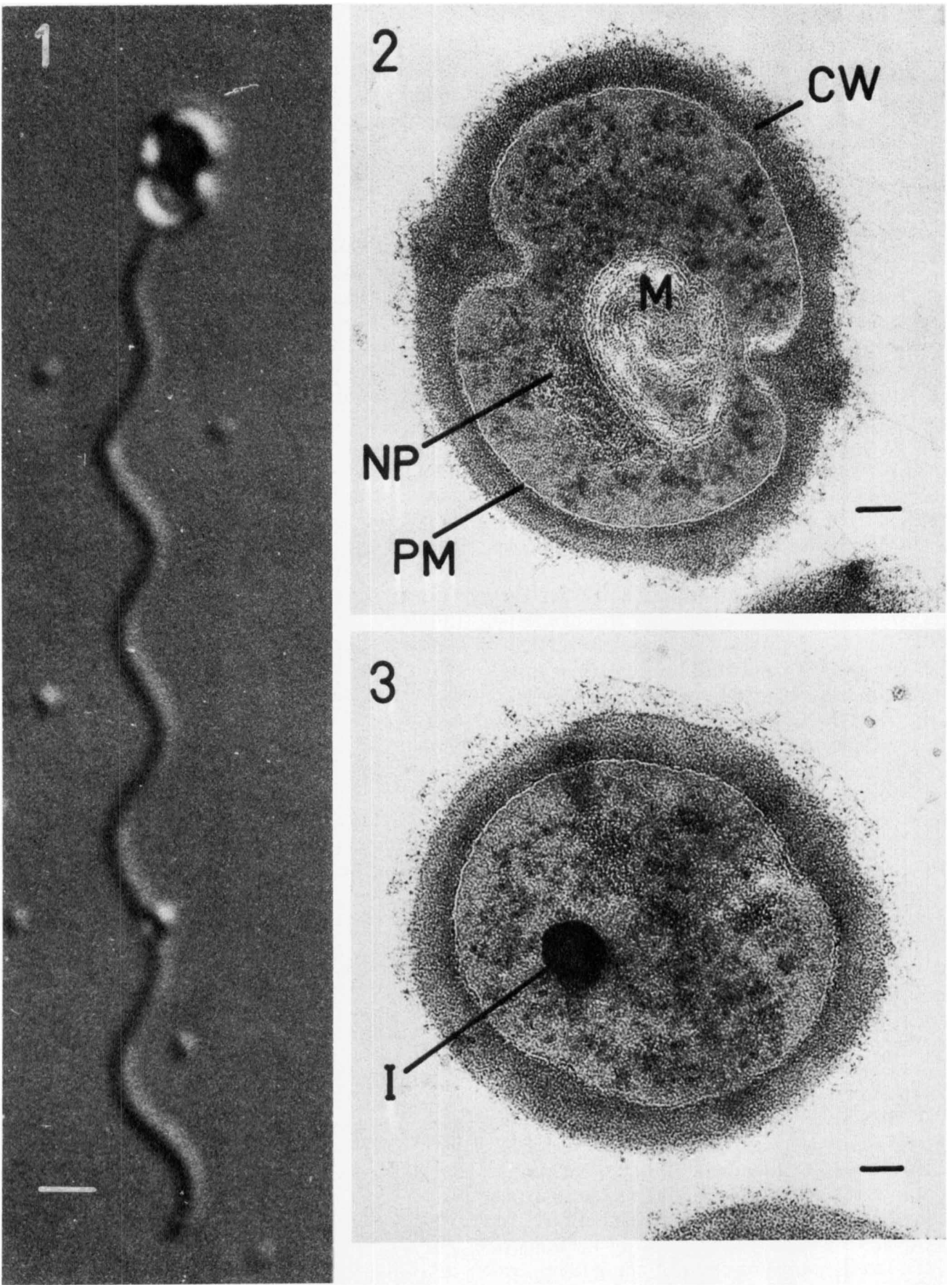

Fig. 1. Light micrograph of NRC 14033 showing paired cell arrangement and single flagellum. The bar represents $1.0 \mu \mathrm{m}$.

FIG. 2. Electron micrograph of a thin section of NRC 14033 showing nucleoplasm (NP), mesosome (M), plasma membrane $(P M)$, and the cell wall $(C W)$. The bar represents $0.1 \mu \mathrm{m}$.

FIG. 3. Electron micrograph of a thin section of NRC 14033 showing inclusion body (I). The bar represents $0.1 \mu \mathrm{m}$. 
TABLE 1. Amino acid and amino sugar composition of the peptidoglycan of NRC 14033

\begin{tabular}{lcc}
\hline \multicolumn{1}{c}{ Component } & $\begin{array}{c}\text { Amt } \\
\text { (nmol/mg) }\end{array}$ & $\begin{array}{c}\text { Molar ratio } \\
\text { (glucosamine =1) }\end{array}$ \\
\hline Glucosamine & 387 & 1.00 \\
Muramic acid & 139 & 0.36 \\
Alanine & 915 & 2.36 \\
meso-DAP & 955 & 2.47 \\
Glutamic acid & 1,107 & 2.86 \\
\hline
\end{tabular}

D. J. Kushner, unpublished results) and may be regarded as the true "Micrococcus $\mathrm{H}_{5}$." We have also obtained another culture of NRCC 14033 from the culture collection of the NRCC. This culture had been maintained on the medium of Sehgal and Gibbons (containing 20\% $\mathrm{NaCl})$ at $4 \mathrm{C}$. When compared with the culture of NRCC 14033 which we have maintained since 1965 , no significant differences were noted. Neither of the NRCC cultures resembled the NCMB culture with respect to salt response, pigmentation, starch hydrolysis, nitrate reduction, and growth at $37 \mathrm{C}$. At this point we can only speculate on the origin of NRCC 14033. Possibly the "present" NRCC 14033 arose as a contaminant in the original culture (or later transfer) of "Micrococcus $\mathrm{H}_{5}$." (Both the NRCC and the NCMB collections report receiving their original cultures from Venkataraman.) It is interesting to note that even though NRCC 14033 is not an obligate halophile, its growth on Sehgal and Gibbons medium containing $25 \% \mathrm{NaCl}$ is much greater than that of cultures of the obligate halophiles Halobacterium salinarium and Halococcus morrhuae (T. J. Novitsky and D. J. Kushner, unpublished results).

We propose placing NRCC 14033 in the genus Planococcus, which includes the motile, nonsporeforming, marine cocci $(9,11)$. Classification was based mainly on the organism's motility, $\mathrm{G}+\mathrm{C}$ content, and its strict aerobic nature. Electron micrographs of thin sections of NRCC 14033 closely resemble those of the neotype strain of the type species of the genus Planococcus, P. citreus Czechoslovak Collection of Microorganisms (CCM) 316 (M. Kocur, personal communication). We consider NRCC 14033 as belonging to a new species mainly because of its cell wall composition and its growth response to salt. The name Planococcus halophilus is proposed for this new species. The etymology of the specific epithet is as follows: hal.o.phi'lus. Gr. n. hals, halos the sea, salt; Gr. adj. philus loving; M. L. adj. halophilus salt-loving.

Although all planococci studied previously show good growth in media containing no added salt or seawater medium, only a few could grow in media with $15 \% \mathrm{NaCl}$ (11). NRCC 14033 cannot normally grow in media without added salt, grows best in 6 to $12 \% \mathrm{NaCl}$, and can grow, albeit poorly, in media saturated with $\mathrm{NaCl}(16)$.

This organism also differs from the other planococci in possessing meso-DAP as a major peptidoglycan constituent of its cell wall rather than L-lysine (21). It is not known at this time whether the amino acid sequence of the cell wall peptidoglycan of NRCC 14033 is similar to that of the other planococci, with the exception of the substitution of meso-DAP for L-lysine. Work is presently under way in our laboratory to determine this.

Our initial results have also shown that a difference exists in the relative amounts of peptidoglycan components when the organism is grown at different salt concentrations. Specifically, the proportion of glutamic acid is increased with increasing $\mathrm{NaCl}$ concentration (Novitsky and Kushner, unpublished results). This finding may have important taxonomic implications, since it has been generally thought that the peptidoglycan is a very stable (with regard to environmental change) bacterial component (22).

It is also interesting to note that NRCC 14033 is gram variable, whereas the other planococci are gram positive, possibly reflecting the chemical difference in their cell walls.

NRCC 14033 has been deposited in the American Type Culture Collection (ATCC no. 27964), and it is the type strain by monotypy.

\section{ACKNOWLEDGMENTS}

This study was supported by NRCC grant number A2816

We wish to thank M. Kocur and N. E. Gibbons for their helpful advice. K. Johnson gave invaluable help with the amino acid and amino sugar analyses.

\section{REPRINT REQUESTS}

Address reprint requests to: Dr. D. J. Kushner, Department of Biology, University of Ottawa, Ottawa, Ontario K1N 6N5, Canada.

\section{LITERATURE CITED}

1. Anderson, H. 1954. The reddening of salted hides and fish. Appl. Microbiol. 2:64-69.

2. Deibel, R. H., and J. B. Evans, 1960. Modified benzidine test for the detection of cytochrome-containing respiratory systems in microorganisms. J. Bacteriol. 79:356-360.

3. Ewing, W. H. 1960. Enterobacteriaceae. Biochemical methods for group differentiation. Health Serv. Publ. 734:1-30.

4. Gaby, W. L., and C. Hadley. 1957. Practical laboratory test for the identification of Pseudomonas aeruginosa. J. Bacteriol. 74:356-358.

5. Gibbons, N. E. 1957. The effect of salt concentration on 
the biochemical reactions of some halophilic bacteria. Can. J. Microbiol. 3:249-255.

6. Gibbons, N. E. 1969. Isolation, growth and requirements of halophilic bacteria, p. 169-183. In J. R. Norris and D. W. Ribbons (ed.), Methods in microbiology, vol. 3B. Academic Press Inc., New York.

7. Gore, S. N. 1921. The cotton-wool test for indole. Indian J. Med. Res. 8:505-507.

8. Hucker, G. J. 1927. Further studies on the methods of Gram staining. N. Y. State Agr. Exp. Sta. Tech. Bull. 128

9. Kocur, M. 1974. Planococcus Migula 1864, pp. 489-490 In R. E. Buchanan and E. N. Gibbons (ed.), Bergey's manual of determinative bacteriology, 8th ed. The Williams and Wilkins Co., Baltimore.

10. Kocur, M., and W. Hodgkiss. 1973. Taxonomic status of the genus Halococcus Schoop. Int. J. Syst. Bacteriol. 23:151-156.

11. Kocur, M., Z. Pácǒvá, W. Hodgkiss, and T. Martinec. 1970. The taxonomic status of the genus Planococcus Migula 1894. Int. J. Syst. Bacteriol. 20:241-248.

12. Leifson, E. 1960. Atlas of bacterial flagellation, p. 3-7. Academic Press Inc., New York.

13. Leifson, E. 1963. Determination of carbohydrate metabolism of marine bacteria. J. Bacteriol. 85:1183-1184.

14. Marmur, J. 1961. A procedure for the isolation of deoxyribonucleic acid from microorganisms. J. Mol. Biol. $3: 208-218$.

15. Marmur, J., and P. Doty. 1962. Determination of the base composition of deoxyribonucleic acid from its thermal denaturation temperature. J. Mol. Biol. 5:109-118.

16. Novitsky, T. J., and D. J. Kushner. 1975. Influence of temperature and salt concentration on the growth of a facultatively halophilic 'Micrococcus' sp. Can. J. Microbiol. 21:107-110.

17. Paik, G. 1970. Reagents, stains and test procedures, p. 675-692. In J. E. Blair, E. H. Lennette, and J. P. Truant (ed.), Manual of clinical microbiology. Americal Society for Microbiology, Bethesda.
18. Reynolds, E. S. 1963. The use of lead citrate at high $\mathrm{pH}$ as an electron-opaque stain in electron microscopy. J. Cell Biol. 17:208-212.

19. Rhuland, L. E., E. Work, R. F. Denman, and D. S. Hoare. 1955. The behavior of the isomers of $\alpha$-diaminopimelic acid on paper chromatograms. J. Am. Chem. Soc. 77:4844-4846.

20. Ryter, A., E. Kellenberger, A. Birch-Anderson, and O. Maaloe. 1958. Etude au microscope electronique de plasmas contenant de l'acide desoxyribonucleique. I. Les nucleosides des bactéries en croissance active. $Z$. Naturforsch. 13b: 597-605.

21. Schleifer, K. H., and O. Kandler. 1970. Amino acid sequence of the murein of Planococcus and other $\mathrm{Mi}$ crococcaceae. J. Bacteriol. 103:387-392.

22. Schleifer, K. H., and O. Kandler. 1972. Peptidoglycan types of bacterial cell walls and their taxonomic implications. Bacteriol. Rev. 36:407-477.

23. Seghal, S. N., and N. E. Gibbons. 1960. Effect of some metal ions on the growth of Halobacterium cutirubrum. Can. J. Microbiol. 6:165-169.

24. Smith, N. R., R. E. Gordon, and F. E. Clark. 1946. Aerobic mesophilic sporeforming bacteria. U. S. Dept. Agr. Misc. Publ. 559.

25. Sneath, P. H. A. 1956. Cultural and biochemical charac teristics of the genus Chromobacterium. J. Gen. Microbiol. 15:70-98.

26. Spurr, A. R. 1969. A low-viscosity epoxy resin embedding medium for electron microscopy. J. Ultrastruct. Res. 26:31-43.

27. Ulitzur, S. 1972. Rapid determination of DNA base composition by ultraviolet spectroscopy. Biochim. Biophys. Acta 272:1-11.

28. Venkataraman, R., and S. Sreenivasan. 1954. Studies on the red halophilic bacteria from salted fish and salt. Proc. Indian Acad. Sci. 39b:17-23.

29. Vera, H. D., and M. Dumoff. 1970. Culture media, p. 633-674. In J. E. Blair, E. H. Lennette, and J. P. Truant (ed.), Manual of clinical microbiology. American Society for Microbiology, Bethesda. 